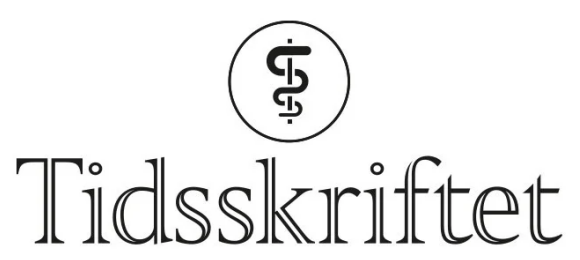

DEN NORSKE LEGEFORENING

\title{
Hva teller når du vil bli professor?
}

FRA ANDRE TIDSSKRIFTER

KETIL SLAGSTAD

Tidsskriftet

Tradisjonelle kriterier for akademiske meritter teller mest ved tilsetting på medisinske fakulteter.

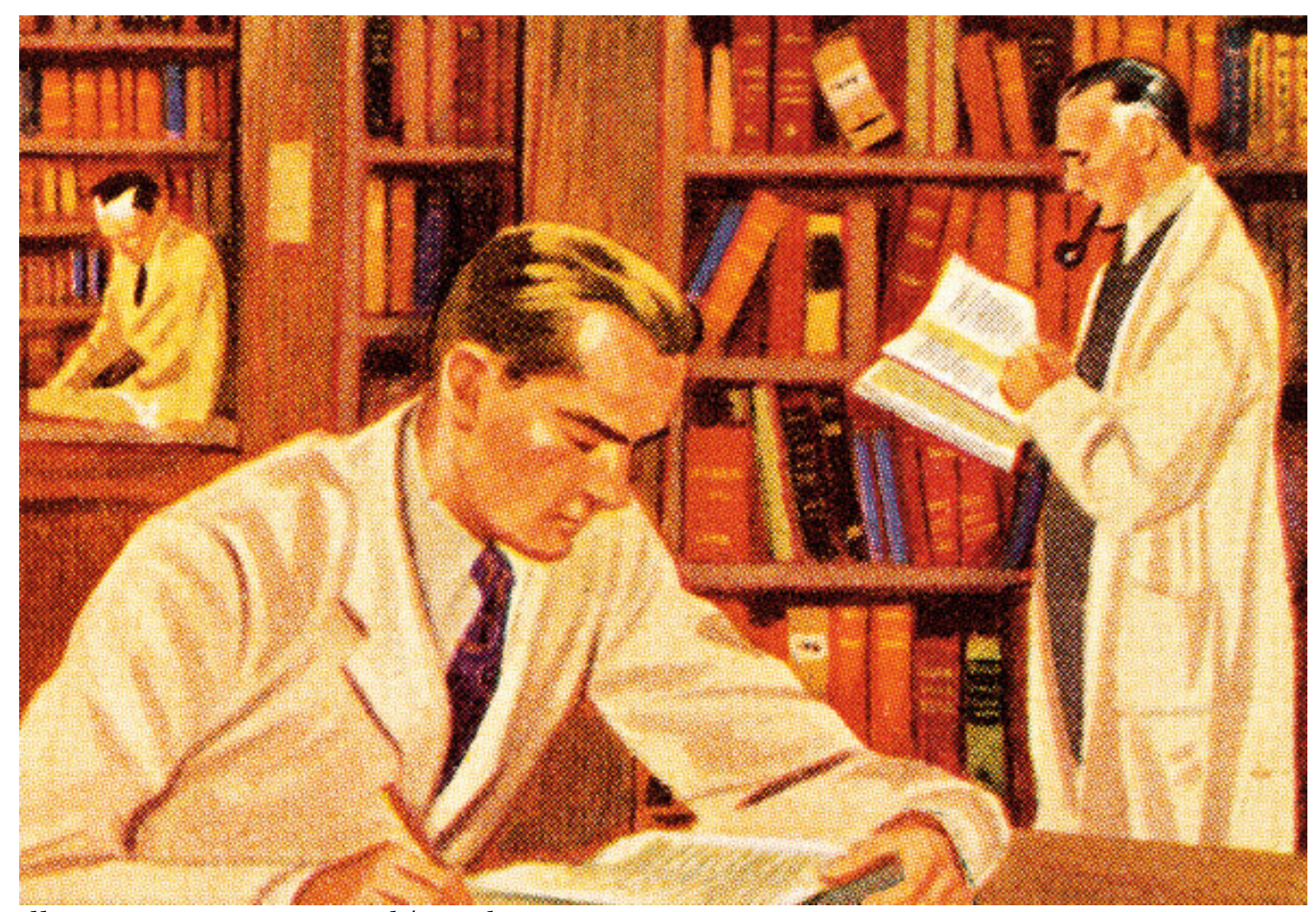

Illustrasjon: CSA-Printstock/iStock

Hvilke kriterier ligger til grunn når forskere på medisinske fakulteter får opprykk eller fast stilling? I en ny studie publisert i tidsskriftet The BMJ ble retningslinjene for slike avgjørelser på 92 universiteter over hele verden gjennomgått (1).

Det vanligste kriteriet i retningslinjene var fagfellevurderte publikasjoner (95\%) og tildelte forskningsmidler (67\%). Blant mindre vanlige kriterier var akademisk omdømme, forfatterrekkefølge i publikasjoner og impaktfaktor. Ytterst sjelden ble kriterier som 
måleverktøy for forskningsbetydning, f.eks. Altmetric, tatt med, og kun ved ett universitet var deling av forskningsresultater nevnt. Ingen universiteter hadde åpen publisering eller riktig registrering av forskningsprosjekter som kriterier i tilsettingsprosessen.

- Denne studien viser at det ikke finnes globale kriterier for tilsetting ved et universitet, og at kriteriene ikke er formulert eksplisitt, sier Johanne Sundby. Hun er professor i samfunnsmedisin ved Universitetet i Oslo og har sittet i utallige bedømmelseskomitéer.

- Vi vet ikke hvilke normer som styrer valg av kriterier, og dermed vil alle bedømmelser ha et element av vilkårlighet. Som kvinneforsker vil jeg anta at en del av kriteriene er laget av og for menn, sier hun, og trekker fram historien om en kvinne som fikk to ulike bedømmelser på samme søknad.

- Den ene sa at hun var veldig flink til å samarbeide, noe som var et pluss, mens den andre sa at hun ikke kunne dokumentere individuell innsats, noe som trakk ned. Jeg tror det er på høy tid at vi ser over og tenker nytt rundt hvem vi vil ha som ledere i medisinsk kunnskapsproduksjon, sier Sundby.

\section{LITTERATUR}

1. Rice DB, Raffoul H, Ioannidis JPA et al. Academic criteria for promotion and tenure in biomedical sciences faculties: cross sectional analysis of international sample of universities. BMJ 2020;369: m2081. [PubMed][CrossRef]

Publisert: 16. september 2020. Tidsskr Nor Legeforen. DOI: 10.4045/tidsskr.20.0662

(C) Tidsskrift for Den norske legeforening 2023. Lastet ned fra tidsskriftet.no 26. april 2023. 